\title{
Extraction of Catecholamine from Mouse Tissues by lon-exchange Chromatography and Its Determination by HPLC
}

H. Dohr*, S. SaKaI, K. Kohmoto and Y. Shoda

Department of Animal Breeding, University of Tokyo, Tokyo 113

(Received March 1, 1985)

\begin{abstract}
Catecholamine was extracted from various tissues of mice by Amberlite CG50 column chromatography with high recoveries (more than 90\%). Epinephrine, norepinephrine and dopamine were separated by high-pressure liquid chromatography with a reversed-phase column and an electrochemical detector and simultaneously measured by the reading of peak heights on the high-pressure liquid chromatographic recorder. Correlation between the peak height and the amount of standards applied to the column was high $(r=0.99)$. Inter - and intra-assay coefficients of variation were less than 2.6 and $3.0 \%$, respectively. The detection limit (signal/noise $>2$ ) was 75 fmol for norepinephrine and $100 \mathrm{fmol}$ for epinephrine and dopamine. When tissue samples were applied onto alumina columns, some unidentified substances were extracted with catecholamines. However, these unidentified substances were removed by selective adsorption to CG50 columns and, even if present, did not interfere with measurement of catecholamine. These results suggest that this method can be gencrally applied to the measurement of endogenous catecholamines.

Jpn. J. Zootech. Sci., 56 (8): 673-679, 1985
\end{abstract}

Dopamine (DA) has a potential inhibitory activity on prolactin (PRL) release in vitro $^{1,2}$ and appears to control PRL secretion through the hypothalamus-pituitary portal system $^{3,4}$. Since the amount of catecholamine in tissues is relatively small, development of a sensitive method is really needed to measure catecholamine especially from tissues of small experimental animals.

High pressure liquid chromatography (HPLC) has a high resolution to separate a variety of substances including catecholamines. Furthermore, an electrochemical detector (ECD) is specific and sensitive enough to detect catecholamines. For application of samples onto HPLC columns, catecholamines should be crudely extracted. Alumina $\left(\mathrm{Al}_{2} \mathrm{O}_{3}\right)$ columns have been commonly used for this purpose. However, selective adsorption of catecholamine onto alumina was influenced by many factors ${ }^{5}$. Amberlite CG50, cation exchanger, also adsorbs monoamines, their precursor amino acids and their metabolites with a high recovery. This ion-exchange resin was mainly used for chromatographic separation of catecholamines ${ }^{6-8}$. Recently, Amberlite CG50 was used for selective adsorption of catecholamines in human urine and rat serum samples prior to the detection of catecholamines by HPLC with fluorometry ${ }^{9)}$

Present address: ${ }^{*}$ Ecology Division, National Grassland Research Institute, Nishinasuno, Tochigi $329-27$ 
or $\mathrm{ECD}^{10)}$. Searching for a method to extract catecholamines, we found that a single step of Amberlite CG50 chromatography can do this effectively.

In this paper, we describe a simple assay method and its application to the measurement of catecholamines in various tissue samples. Catecholamines released from hypothalami into the medium during incubation were also measured for comparison with the amounts contained in the tissues. We observed that catecholamines were extracted by Amberlite CG50 with good recovery and high specificity, and that the same species of tissue catecholamines as reported by others ${ }^{5,11,12)}$ were detected in comparable amounts by HPLC-ECD.

\section{Materials and Methods}

\section{Chemicals and Reagents}

Amberlite CG50 (type II) was from Tokyo Organic Chemical Co. (Tokyo), licenced maker of Rohm and Haas Co.. DA, epinephrine (E) and norepinephrine (NE) were obtained from Sigma Chemical Co. (St. Louis, MO., U.S.A.). These standards were dissolved in $0.1 \mathrm{~N} \mathrm{HClO}_{4}$ and stored at $-20^{\circ} \mathrm{C}$. Water was deionized and doubly distilled. MEM alpha medium $(\alpha-\mathrm{MEM})$ was purchased from Grand Island Biological Co. (Grand Island, NY, U.S.A.). All other chemicals were of analytical reagent grade.

\section{Activation of Amberlite $C G 50$}

Amberlite resin $(50 \mathrm{~g})$ was first suspended in water, and fine particles were removed several times by decantation. The resin was then suspended in $500 \mathrm{~m} l$ of $2 \mathrm{~N}$ $\mathrm{HCl}$ for $30 \mathrm{~min}$ with stirring, washed extensively with plenty of water until $\mathrm{pH}$ was almost neutral, suspended in $500 \mathrm{~m} l$ of $2 \mathrm{~N} \mathrm{NaOH}$ for 30 min followed by washing with water as described above, and finally equilibrated with $0.1 \mathrm{M} \mathrm{NaH}_{2} \mathrm{PO}_{4}-\mathrm{K}_{2} \mathrm{HPO}_{4}(\mathrm{pH}=$ 6.5) containing $1 \mathrm{mM}$ EDTA. The activated resin was packed to a height of $5 \mathrm{~cm}$ in a small glass column $(0.5$ i.d. $\times 10 \mathrm{~cm})$.

Separation and quantitation of catecholamine

HPLC-ECD consisted of high-pressure pump with a pressure gauge and limiter (NSP-800-500 X, Nippon Seimitsu, Tokyo), a sample injector (NVI-3001, Nippon Seimitsu), a reversed-phase column (LiChrosorb RP-18, $5 \mu \mathrm{m}, 0.4 \times 25 \mathrm{~cm}$, Merck, Darmstadt, Germany) and an electrochemical detector (E-308, Irika, Kyoto). Carrier buffer was constituted of $0.1 \mathrm{M}$ citric acid-0.05 M ammonium acetate $(\mathrm{pH}=3.0)$ $2 \mathrm{mM}$ EDTA $-1.25 \mathrm{mg} / \mathrm{l}$ SDS, and filtered through a nitrocellulose membrane $(0.2 \mu \mathrm{m})$ before use. The flow rate and applied potential were set at $1 \mathrm{ml} / \mathrm{min}$ and $+0.7 \mathrm{~V}$, respectively. This procedure was carried out at room temperature.

\section{Extraction of catecholamine}

Fresh tissues (approximately 3 to $10 \mathrm{mg}$ ) were removed and homogenized in 0.5 $\mathrm{m} l$ of $0.5 \mathrm{M} \mathrm{HClO} 4$ immediately after dd mice were killed by cervical dislocation. Blood was collected by heart puncture and centrifuged at $12000 \times \mathrm{g}$ for $5 \mathrm{~min}$ to obtain blood plasma. Aqueous samples (blood plasma and $\alpha$-MEM media collected after incubation of hypothalamus for $120 \mathrm{~min}$ ) were mixed with an equal vol of $0.5 \mathrm{M} \mathrm{HClO}_{4}$ 
by vortexing. All samples were with dihydrobenzylamine (DHBA; $1 \mathrm{ng}$ in $10 \mu \mathrm{l}$ of the above solution) as internal standard to monitor recovery. The sample was kept at $4^{\circ} \mathrm{C}$ for $30 \mathrm{~min}$ and centrifuged at $12000 \times \mathrm{g}$ for $15 \mathrm{~min}$. The pellet was used for protein determination by the Lowry's method. The supernatant was centrifuged at $1000 \times \mathrm{g}$ for $10 \mathrm{~min}$ to remove insoluble $\mathrm{KClO}_{4}$ after the $\mathrm{pH}$ was adjusted to $6.5-7.5$ with $0.4 \mathrm{M} \mathrm{K}_{2} \mathrm{CO}_{3}$. One-fifth vol of $0.5 \mathrm{M} \mathrm{NaH}_{2} \mathrm{PO}_{4}-\mathrm{K}_{2} \mathrm{HPO}_{4}(\mathrm{pH}=6.5$ ) containing $1 \mathrm{mM}$ EDTA was added. The sample was applied onto an Amberlite CG50 column $(0.5 \times 5 \mathrm{~cm})$. After drained off, the column was washed with $10 \mathrm{ml}$ of ice-cold water and subsequently with $1.5 \mathrm{ml}$ of $0.5 \mathrm{~N} \mathrm{HCl}-1 \mathrm{mM}$ EDTA and the eluate was lyophilized thoroughly. The dried sample was dissolved in $150 \mu \mathrm{l}$ of $0.1 \mathrm{~N} \mathrm{HClO}_{4}$ and centrifuged at $12000 \times \mathrm{g}$ for $15 \mathrm{~min}$ prior to injection. The supernatant $(100 \mu \mathrm{l})$ was injected to HPLC-ECD.

\section{Results}

DA, DHBA, E and NE were adsorbed onto Amberlite CG50 and eluted completely with $0.5 \mathrm{~N} \mathrm{HCl}$. Recoveries of these standards in the process of CG50 chromatography were virtually $100 \%(102.1 \pm 4.4 \%, 108 \pm 3.8 \%, 102.7 \pm 3.8 \%$ and $100.1 \pm$ $1.2 \%$ for DA, DHBA, $\mathrm{E}$ and $\mathrm{NE}$, respectively, $\mathrm{M} \pm \mathrm{SD}, \mathrm{n}=3$ ). In Fig. 1 (A), these standards were clearly separated into independent sharp peaks in the chromatogram. Linear dose-response relationship was observed between the amount and the peak height for each standard $(r=0.99)$, as shown in Fig. 1 (B). Intra-assay vari-
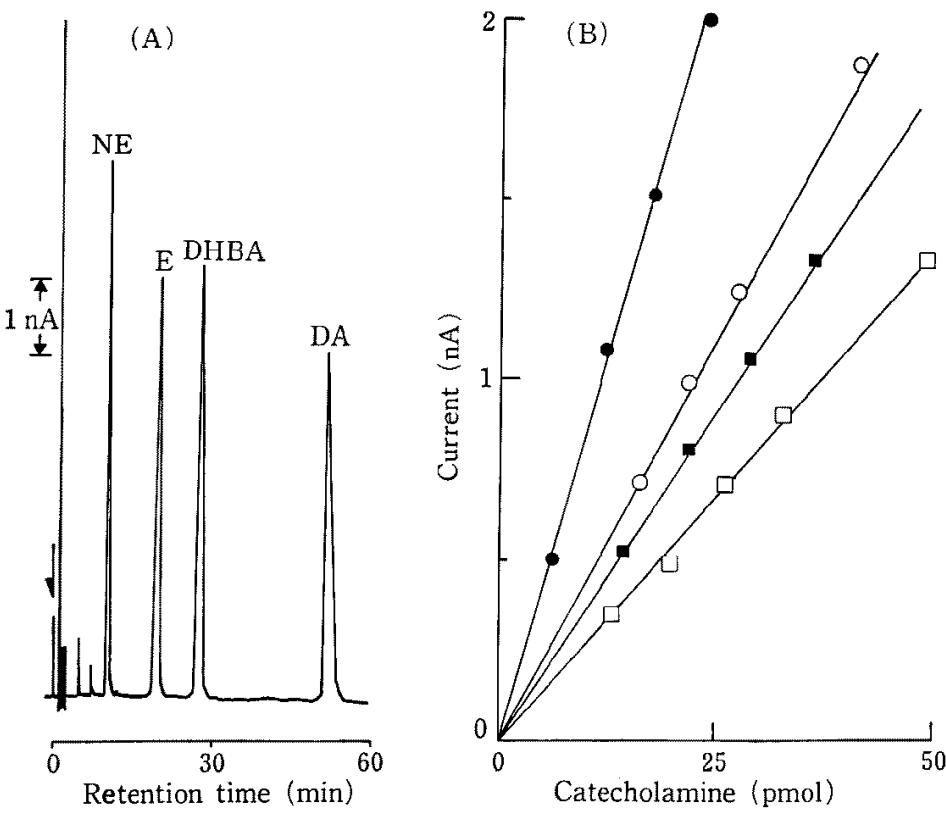

Fig. 1. Chromatogram (A) and standard curves (B) for NE, E, DHBA, and DA generated in HPLC-ECD. Catecholamines dissolved in $100 \mu l 0.5 \mathrm{~N} \mathrm{HCl}$ were in jected to HPLC-ECD. The sensitivities were $8 \mathrm{nA}$ (A) and $2 \mathrm{nA}$ (B), respectively. 


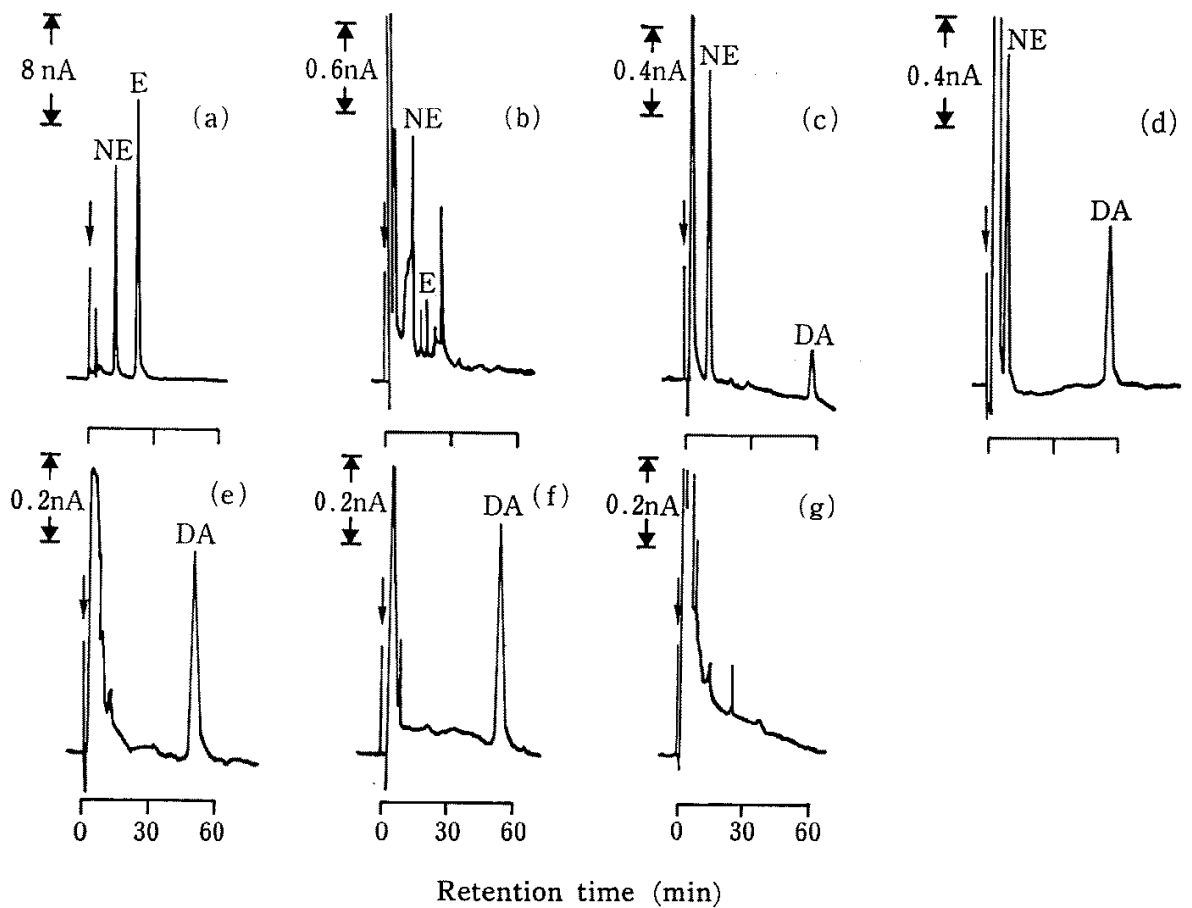

Fig. 2. Chromatograms of catecholamines extracted by Amberlite CG 50 from various samples. To obtain the height of peaks on chromatograms, $1 \mu \mathrm{g}$ adrenal gland (a), $20 \mu \mathrm{g}$ hypothalamus (C), $350 \mu \mathrm{g}$ anterior pituitary (e), $50 \mu \mathrm{g}$ posterior pituitary (f), $500 \mu \mathrm{g}$ lung (g) in terms of protein weight in tissues, $500 \mu l$ blood plasma (b) and medium in which 3 hypothalami had been cultured for $2 \mathrm{hr}$ (d) were prepared as described in the text.

ance of each standard was relatively small $(2.6 \%, 1.4 \%, 2.6 \%$ and $2.2 \%$ for DA, DHBA, $\mathrm{E}$ and NE, respectively C. V., $\mathrm{n}=4$ ). Inter-assay variance was less than $3 \%$ $(n=3)$. Minimal detectable amounts of standards (signal/noise $>2$ ) were approximately $100 \mathrm{fmol}$ in DA, DHBA and E, and $75 \mathrm{fmol}$ in NE, respectively. Recoveries of catecholamines added to hypothalamic homogenates were more than $90 \%$ with small SD $(90.0 \pm 5.0 \%, 92.6 \pm 4.1 \%, 90.9 \pm 3.5 \%$ and $91.2 \pm 2.4 \%$ for DA, DHBA, E and $\mathrm{NE}$, respectively, $\mathrm{M} \pm \mathrm{SD}, \mathrm{n}=7$ ). In other tissue homogenates also over $90 \%$ of recoveries was resulted (data not shown).

Catecholamines in various tissues were extracted and measured according to the procedure described above. As shown in Fig. 2, each chromatogram shows clear separation of catecholamines and minimum contamination of unidentified substances which interfere with the identification and measurement of catecholamines from tissue samples. When the samples from the medium incubated with hypothalami were applied onto alumina, the eluate contained two unidentified substances. These substances made it difficult to measure catecholamines. Such impurities were, however, eliminated by passing the medium through a column of Amberlite CG 50 .

Contents of catecholamines obtained from peak heights of the chromatogram were summarized in Table 1. Adrenal glands contained the largest amounts of both $\mathrm{E}$ and 
Determination of Catecholamines by HPLC

Table 1. Endogenous catecholamine contents in various mouse tissues

\begin{tabular}{|c|c|c|c|}
\hline Tissue & Norepinephrine & Epinephrine & Dopamine \\
\hline $\begin{array}{l}\text { Adrenal gland } \\
\text { (n mol/mg protein) }\end{array}$ & $7.27 \pm 1.34$ & $16.12 \pm 1.66$ & N. D. \\
\hline $\begin{array}{l}\text { Blood plasma } \\
\text { (p mol/ml plasma) }\end{array}$ & $13.2 \pm 1.2$ & $6.5 \pm 1.77$ & N. D. \\
\hline $\begin{array}{l}\text { Hypothalamus } \\
\text { (p mol/mg protein) }\end{array}$ & $69.2 \pm 13.4$ & N. D. & $41.8 \pm 6.5$ \\
\hline $\begin{array}{l}\text { Lung } \\
\text { ( } \mathrm{p} \mathrm{mol} / \mathrm{mg} \text { protein })\end{array}$ & N. D. & N. D. & N. D. \\
\hline $\begin{array}{l}\text { Pituitary anterior } \\
\text { (p mol/mg protein) }\end{array}$ & N. D. & N. D. & $4.37 \pm 1.04$ \\
\hline $\begin{array}{l}\text { Pituitary posterior } \\
\text { (p mol/mg protein) }\end{array}$ & N. D. & N. D. & $38.56 \pm 3.99$ \\
\hline $\begin{array}{l}\text { Hypothalamic culture } \\
\text { (p mol/mg protein) }\end{array}$ & $13.4 \pm 1.77$ & N. D. & $21.5 \pm 1.36$ \\
\hline$M \pm S . D . \quad(n=3)$ & N. D. $<75$ f mol & N. D. $<100 \mathrm{f} \mathrm{mol}$ & N. D. $<100 \mathrm{f} \mathrm{mol}$ \\
\hline
\end{tabular}

NE among tissues tested. On the contrary none of these catecholamines was detected in the lung. Anterior and posterior pituitary glands had DA alone. Posterior pituitary glands (neural lobes) contained larger amounts of DA than anterior glands. The hypothalamus was rich in NE but actively secreted DA into culture medium. E was detected only in adrenal glands.

\section{Discussion}

Alumina has been widely used to extract catecholamines by many investigators ${ }^{5}$. 13.14). Our data show that Amberlite CG50 also adsorbed catecholamines selectively. The recoveries of catechojamine in the process of extraction from tissue homogenate were more than 90\%, in agreement with $\mathrm{SEKI}^{7)}$ and $\mathrm{JACKMAN}^{9)}$. Alumina adsorbs non-catecholamine substances ${ }^{5.14}$. Such substances may interfere with measurement of catecholamine by HPLC-ECD. We also observed that unidentified substances were extracted with catecholamines from blood samples by alumina and disturbed measurement of catecholamine as described in Kato et al. ${ }^{10)}$ in medium samples, two unidentified substances which were adsorbed onto alumina were not adsorbed onto Amberlite CG50. The HPLC-ECD has enough sensitivity to measure endogenous catecholamines, being almost comparable to radioenzymatic procedure ${ }^{15)}$, gas chromatography with mass spectrometry ${ }^{16)}$ or HPLC with fluorescence detection ${ }^{17)}$.

Endogenous catecholamines summarized in Table 1 were compared below to the figures reported by others. Amounts of $\mathrm{E}$ and $\mathrm{NE}$ in adrenal glands were in good agreement with Anton \& Sayre ${ }^{5}$. They found that small amounts of these catecholamines existed in the lung. We could not detect either $\mathrm{E}$ or $\mathrm{NE}$, presumably due to the difference in the sensitivity of assay methods. The hypothalamus contained catecholamines of the same kind and of comparable amounts to those in the hypothalamus of female Snell mice and rats ${ }^{12.18)}$. In the superfused rat hypothalamus, almost equal moles of $\mathrm{NE}$ and DA were secreted ${ }^{19}$. Our data that DA in posterior pituitary 
glands is much higher than in anterior glands also agreed with those of BEN-JoNATHAN \& PORTER ${ }^{12)}$. The DA content in rat pituitary glands ${ }^{12.20)}$ are even lower than our data in mice. Some unidentified peaks were observed on the chromatogram of blood samples. These substances may be different from the ones in medium samples because they cannot be removed by the use of CG 50 resin. Even though these unidentified substances are present, NE, E and DA in blood samples are measurable by the HPLCECD system because the retention times of these unidentified substances are different from those of NE, $E$ and DA. The molar ratio of $\mathrm{NE} / \mathrm{E}$ in blood plasma was almost identical, while, amounts of catecholamines in plasma greatly differed depending on investigators ${ }^{6,21,22}$. Our data indicate that the extraction of tissue catecholamine by Amberlite CG50 has good recovery and specificity, and that HPLC-ECD is a suitable system for accurate determination. We conclude, therefore, that our procedures are applicable for measurement of low levels of catecholamine of small samples from mouse tissues.

\section{References}

1) MacLeod, R. H. and J. E. Lehmeyer, Endocrinology 94: 1077-1084. 1974.

2) ShaAr, C. J. and J. A. Clemens, Endocrinology 95: 1202-1212. 1974.

3) Takahara, J., A. Arimura and A.V. Schally, Endocrinology 95: 462-465. 1974.

4) Gibвs, D. M. and J. D. Neill, Endocrinology 102: 1895-1900. 1978.

5) Anton, A. H. and D.F. SAyre, J Phamacol Exp Ther 138: 360-375. 1962.

6) Minard, F. N. and D. S. Grant, Biochem Med 6: 46-52. 1972.

7) Sekr, T., J Chromatogr 124: 411-414. 1976.

8) Sекі, T., J Chromatogr 155: 415-420. 1978.

9) Jackman, G. P., Clin Chem 26: 1623-1624. 1980.

10) Kato, T., K. Koshiya and T. Nagatsu, Protein Nucleic Acid Enzyme 26, 1129-1134. 1981. (in Japanese)

11) Kissinger, P. T., C. J. Refashauge, R. Drelling and R. N. Adams, Anal Lett 6: 465-477. 1973.

12) Ben-Jonathan, N. and J. C. Porter, Endocrinology 98: 1497-1507. 1976.

13) Refshauge, C. J., P. T. Kissinger, L. Dreinign, L. Blank, R. Freeman and R. N. Adams, Life Sci 14: 311-322. 1974.

14) Maruyama, Y. and M. Kusaka, Life Sci 23: 1603-1608. 1978.

15) Peuler, J. D. and G. A. Johnson, Life Sci 21: 625-636. 1977.

16) Jacob, K., W. Vogr, M. Knedel and G. Schwertfegers, J. Chromatogr 146: 221-226. 1978.

17) Yui, Y., M. Kimura, Y. Itokawa and C. Kawai, J Chromatogr 177. 376-379. 1979.

18) Morgan, W. W., A. Bartke and K. Pfeil, Endocrinology 109: 2069-2075. 1981.

19) Foreman, M. M. and J. C. Porter, Endocrinology 108: 800-804. 1981.

20) Chiocchio, S. R., S. Chafuen and J. H. Tramezzani, Endocrinology 106: 1682-1685. 1980.

21) Buhler, H. U., M. Da Prada, W. Haefely and G. B. Picotri, J Physiol 276: 311-320. 1978.

22) Bauce, L., J.A. Thornhill, K. E. Cooper and W. L. Veale, Life Sci 27: 1921-1928. 1980. 


\title{
イオン交換クロマトグラフィーによるカテコールアミンの抽出之
}

高速液体クロマトグラフィーによる測定

\author{
土肥宏志* ・酒井仙吉 $\cdot$ 河本 警 $・$ 正田陽一
}

東京大学農学部, 東京都交京区 113

マウスの生体試料中のノルエピネフリン (NE), シピ ネフリン（E）扎よびドーパミン(DA)は, アンパーラ イトCG 50 により, $90 \%$ 以上の高回収率で抽出された. 抽出されれたカテュールアミンは，逆相系のカラムを用い た高速液体クロマトグラフィーと電気化学的検出器を組 双合わせた方法 (HPLC-ECD 法) に上り分離され，ク ロマトグラム上のピークの高さから，カテコールフミン 量を同時に測定することができた。ピークの高さと量の 間には，高い相関（r=0.99）があり，測定内括よび測定 間変動俰数は，それぞれ $2.6 \%$ と.0\%以下であった。 た，最低検出量は，NEが75 fmol，E扎よび DAか゚ 100 fmolとなり，湘定感度は鋭敏であったささ菓ざななウ スの生体試料に颃いて，カテュールフミンの測定を妨害 する物質は，アンバーライトCG50により除去されて扰 り、クロマトグラム上でカテュールアミンのピークを計 测することができた。

以上の結果加ら，フンバーライト CG50よ HPLC$\mathrm{ECD}$ 法を組み合わせることにより，マウス生体試料中 の微量なカテコールフミンを，正確かつ同時に湘定でき ることが明らかになった。

日畜会報，56(8)：673-679，1985

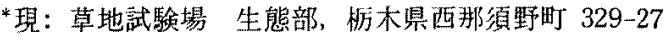

